\title{
POSZKODOWANI W POŻARACH I MIEJSCOWYCH ZAGROŻENIACH, JAKIE MIAŁY MIEJSCE W BUDYNKACH MIESZKALNYCH W POLSCE W LATACH 2000-2006
}

\begin{abstract}
Streszczenie. W artykule przedstawiono skutki osobowe pożarów mieszkań i miejscowych zagrożeń w Polsce w latach 2000-2006. Każdego roku w pożarach traci życie około 500 osób. Większość ofiar przypada na pożary mieszkań, z czego 60-70\% tych przypadków to ofiary zetknięcia $\mathrm{z}$ dymami i toksycznymi produktami spalania. W artykule zaprezentowano przyczyny tak dużych strat osobowych oraz zaproponowano rozwiązanie, które znacząco przyczyni się do poprawy bezpieczeństwa mieszkańców.
\end{abstract}

Słowa kluczowe: zagrożenie pożarowe, ryzyko pożarowe, bezpieczeństwo pożarowe, czujka dymu.

\section{WPROWADZENIE}

Ogień towarzyszy człowiekowi od zarania dziejów. Daje on ciepło, poczucie bezpieczeństwa, ale gdy nie jest kontrolowany niesie śmierć i zniszczenie. Gdy proces spalania materiałów palnych nie jest kontrolowany, mamy do czynienia z pożarem. Powstaje on w miejscu i czasie najbardziej niekorzystnym dla osoby czy podmiotu, którego dotyczy. Dlatego też zabezpieczenia i rozwiązania w zakresie ochrony przeciwpożarowej rosną wraz z wysokością budynku. W wysokim budynku mogą wystąpić efekty kominowe, czyli pożar rozwinie się szybciej, w konsekwencji czego nastąpi znaczny wzrost temperatury. Drogi ewakuacyjne (jedyna droga ucieczki) mogą ulec zadymieniu, a ucieczka osób przebywających w obiekcie nie będzie możliwa. Występuje utrudnione dotarcie ekip ratowniczych do źródła pożaru, co w konsekwencji prowadzi do wydłużenia czasu, jaki upłynie do jego ugaszenia.

W Polsce co roku w pożarach mieszkań giną dziesiątki osób, ok. 60-70\% przypadków to ofiary zetknięcia z dymami i toksycznymi produktami spalania. Bezpośrednią przyczyną śmierci są najczęściej silnie trujące produkty spalania i rozkładu termicznego: tlenek węgla, chlorowodór, cyjanowodór.

Pożary w mieszkaniach powstają pomimo zmian przepisów w zakresie ochrony przeciwpożarowej, rozwoju technologicznego budownictwa mieszkaniowego, poprawy bezpieczeństwa użytkowania urządzeń technicznych.

*Uniwersytet Łódzki, Wydział Ekonomiczno-Socjologiczny, Katedra Ubezpieczeń. 
Osoby poszkodowane w pożarach możemy podzielić na dwie grupy: ofiary śmiertelne i osoby ranne. Artykuł podejmie próbę ukazania skali występowania poszkodowanych w pożarach mieszkaniowych w Polsce i wybranych krajach świata.

Liczba poszkodowanych w stosunku do liczby mieszkańców to ważny wskaźnik bezpieczeństwa pożarowego. Wskaźnik ten oraz inne będą omówione szerzej w dalszej części pracy.

$\mathrm{W}$ artykule przedstawiono skalę poszkodowanych w pożarach mieszkań ${ }^{1}$ w skali Polski na podstawie danych zawartych w bazie danych Komendy Głównej PSP. Tekst został napisany w oparciu o załączoną literaturę.

W dalszej części zaprezentowano analizę statystyczną skutków pożarów w budynkach mieszkalnych, jakie powstały w Polsce w latach 2000-2006. W celu zminimalizowania niekorzystnych wpływów zdarzeń losowych (np. wybuch, pożar, zalanie itp.) właściciele nieruchomości i zakłady ubezpieczeniowe powinny wykorzystywać techniki i działania umożliwiające zmniejszenie strat.

\section{POJECIA PODSTAWOWE}

Pożar jest definiowany w zależności od dziedziny życia, która wykorzystuje to pojęcie do swoich celów. Wśród strażaków i osób zajmujących się bezpieczeństwem pożarowym pożar definiuje się jako niekontrolowany proces spalenia występujący w miejscu do tego nieprzeznaczonym, rozprzestrzeniający się w sposób niekontrolowany, powodujący zagrożenie dla zdrowia i życia ludzi oraz straty materialne.

Kodeks karny w art. $163 \S 1$ mówi, że sprowadzenie zdarzenia niebezpieczne$\mathrm{go}^{2}$, mającego postać pożaru to zdarzenie, które zagraża życiu lub zdrowiu wielu osób albo mieniu w wielkich rozmiarach.

Zakłady ubezpieczeniowe definiują pożar jako działanie ognia, który przedostał się poza palenisko albo powstał bez paleniska i rozprzestrzenił się o własnej sile.

Termin zagrożenie często jest używany i wykorzystywany w opracowaniach technicznych, dlatego rozważania na ten temat prowadzone są w zakresie wiedzy technicznej i możliwości ich wykorzystania w obszarze ekonomii.

Najczęściej spotykanym zagrożeniem w obiektach w czasie całego procesu ubezpieczeniowego jest zagrożenie pożarowe. Zagrożeniem pożarowym budynku mieszkalnego nazywamy zespół elementów budowlanych, instalacyjnych i wyposażenia o określonych parametrach, mających wpływ

\footnotetext{
${ }^{1}$ Ranni i ofiary śmiertelne pożaru lub innych miejscowych zagrożeń w budynkach mieszkalnych.

${ }^{2} \mathrm{~W}$ tym przypadku zdarzeniem określany jest pożar.
} 
na możliwość powstania i rozprzestrzeniania się pożaru. Jest ono uzależnione od wielu czynników, np. rodzaju, ilości i struktury fizycznej materiałów palnych.

Termin ryzyko jest szeroko stosowany zarówno w normalnym życiu każdego człowieka, jak i w świecie nauki. Przykładowo w codziennej dyskusji: ryzyko zachorowania na grypę w czasie zimy jest całkiem wysokie lub: ryzyko utraty życia wskutek upadku statku powietrznego jest bardzo małe. W każdym z obszarów nauki termin ryzyko posiada różne znaczenia o odmiennym charakterze. Istotne jest dokładne poznanie ryzyka $\mathrm{z}$ uwagi na jego charakter i mnogość definicji.

Ryzyko badanego obszaru ulega zmianie w czasie, wydaje się procesem niż stanem. Do określenia pojęcia ryzyka wykorzystywane są dwa elementy (PN-IEC 60300-3-9: 10):

- prawdopodobieństwo - możliwość, szansa wydarzenia się czegoś, bycie prawdopodobnym, np. duże, ogromne, małe, znikome prawdopodobieństwo czegoś,

- konsekwencje ryzyka (szkoda) - uraz fizyczny lub uszczerbek na zdrowiu, uszkodzenie mienia lub degradacja środowiska.

Zapewnienie bezpieczeństwa jest naturalnym dążeniem człowieka. Jest ono rozumiane jako stan niezagrożenia, spokoju, pewności (Kołodziński 2004: 6). W celu uzyskania oczekiwanego bezpieczeństwa każdy człowiek, grupa społeczna czy organy państwa starają się oddziaływać na swoje otoczenie tak, aby eliminować lub minimalizować wszelkiego rodzaju zagrożenia, których źródłem jest drugi człowiek lub siły natury.

\section{METODY POMIARU RYZYKA POŻAROWEGO}

Szukając odpowiedzi na pytanie, jak duże jest ryzyko pożarowe w budynkach mieszkalnych, wielorodzinnych konieczne jest zbadanie częstości (prawdopodobieństwa) występowania pożarów oraz poznanie liczby poszkodowanych osób w tych pożarach.

W Światowej statystyce ochrony przeciwpożarowej i ratownictwa Bruhlinsky (2008: 1) określił ryzyko pożarowe jako prawdopodobieństwo albo częstość szkodliwych oddziaływań w związku z podejmowanymi działaniami, w wyniku których powstają szkody osobowe i materialne.

Autorzy powyższej pozycji zaproponowali szereg miar ryzyka:

$\mathbf{R}_{1}$ Ryzyko zetknięcia się człowieka z pożarem w określonym interwale czasu. Miara ryzyka wykorzystuje następujące zależności opisane wzorem:

$$
R_{1}=\left[\frac{P}{10^{3} \text { Osoby } x \text { Rok }}\right]
$$


gdzie: P - liczba pożarów.

$\mathbf{R}_{2}$ Ryzyko utraty życia lub zdrowia w pożarze przez człowieka. Miara ryzyka wykorzystuje następujące zależności opisane wzorem:

$$
R_{2}=\left[\frac{\text { Ofiary }}{10^{2} P P}\right]
$$

gdzie: PP - liczba pożarów.

$\mathbf{R}_{3}$ Ryzyko utraty życia lub zdrowia przez człowieka w określonym interwale czasu. Miara ryzyka wykorzystuje następujące zależności opisane wzorem:

$$
R_{3}=\left[\frac{\text { Ofiary }}{10^{5} \text { Osoby } x \text { Rok }}\right]
$$

Opisane miary ryzyka zostały przedstawione w tab. 1.

Tabela 1

\begin{tabular}{|c|c|c|c|c|c|c|c|c|c|c|}
\hline Lp. & 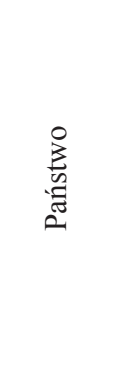 & 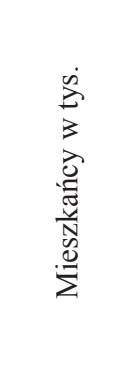 & 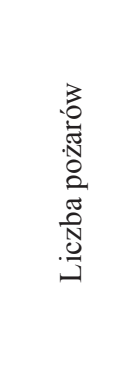 & 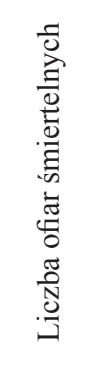 & 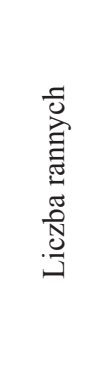 & 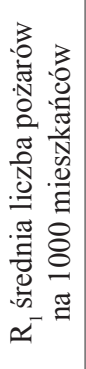 & 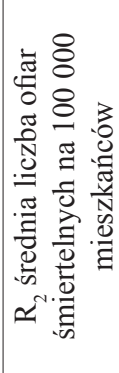 & 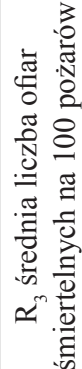 & 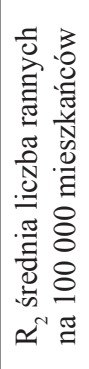 & 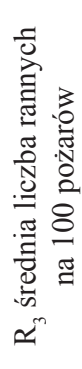 \\
\hline 1 & 2 & 3 & 4 & 5 & 6 & 7 & 8 & 9 & 10 & 11 \\
\hline 1. & Chiny & 1321852 & 223000 & 1517 & 1418 & 0,2 & 0,1 & 0,7 & 0,1 & 0,6 \\
\hline 2. & Indie & 1129868 & 200000 & 8500 & - & 0,2 & 0,8 & 4,3 & - & - \\
\hline 3. & USA & 301140 & 1642500 & 3245 & 16400 & 5,5 & 1,1 & 0,2 & 5,4 & 1,0 \\
\hline 4. & Rosja & 141378 & 220400 & 17223 & 13525 & 1,6 & 12,2 & 7,8 & 9,6 & 6,1 \\
\hline 5. & Niemcy & 82438 & 187604 & 424 & - & 2,3 & 0,5 & 0,2 & - & - \\
\hline 6. & Francja & 63714 & 359300 & 341 & 11192 & 5,6 & 0,5 & 0,1 & 17,6 & 3,1 \\
\hline
\end{tabular}

Miary ryzyka, dla mieszkańców w wybranych państwach świata w roku 2006 


\begin{tabular}{|c|c|c|c|c|c|c|c|c|c|c|}
\hline 1 & 2 & 3 & 4 & 5 & 6 & 7 & 8 & 9 & 10 & 11 \\
\hline 7. & $\begin{array}{c}\text { Wielka } \\
\text { Brytania }\end{array}$ & 60776 & 436047 & 504 & 13600 & 7,2 & 0,8 & 0,1 & 22,4 & 3,1 \\
\hline 8. & Włochy & 58148 & 227014 & 112 & 345 & 3,9 & 0,2 & 0,0 & 0,6 & 0,2 \\
\hline 9. & Polska & 38647 & 165353 & 608 & - & 4,3 & 0,4 & 1,6 & - & - \\
\hline 10. & Holandia & 16571 & 112800 & 80 & 1089 & 6,8 & 0,5 & 0,1 & 6,6 & 1,0 \\
\hline 11 & Węgry & 9956 & 21829 & 131 & 583 & 2,2 & 1,3 & 0,6 & 5,9 & 2,7 \\
\hline 12. & Szwecja & 9031 & 27106 & 83 & 1195 & 3,0 & 0,9 & 0,3 & 13,2 & 4,4 \\
\hline 13. & Austria & 8200 & 30297 & 33 & 854 & 3,7 & 0,4 & 0,1 & 10,4 & 2,8 \\
\hline 14. & Bułgaria & 7323 & 29090 & 96 & 290 & 4,0 & 1,3 & 0,3 & 4,0 & 1,0 \\
\hline 15. & Słowacja & 5448 & 10422 & 49 & 185 & 1,9 & 0,9 & 0,5 & 3,4 & 1,8 \\
\hline 16. & Finlandia & 5239 & 17800 & 119 & 461 & 3,4 & 2,3 & 0,7 & 8,8 & 2,6 \\
\hline 17. & Singapur & 4553 & 4702 & 3 & 91 & 1,0 & 0,1 & 0,1 & 2,0 & 1,9 \\
\hline 18. & Nowa & 4116 & 24405 & 25 & 405 & 5,9 & 0,6 & 0,1 & 9,8 & 1,7 \\
\hline 19. & Litwa & 3575 & 22912 & 307 & 308 & 6,4 & 8,6 & 1,3 & 13,9 & 1,8 \\
\hline 20. & Łotwa & 2294 & 17720 & 235 & 318 & 7,7 & 10,2 & 1,3 & 13,9 & 1,8 \\
\hline 21. & Estonia & 1347 & 14900 & 164 & - & 11,1 & 12,2 & 1,1 & - & - \\
\hline
\end{tabular}

Źródło: Bruhlinsky, Sokolov, Wagner, Hall (2008).

W tab. 1 wskaźnik przedstawiający nam ryzyko wystąpienia pożaru $\mathbf{R}_{1}$ (średnia liczba pożarów na 1000 mieszkańców) kształtuje się od 2 do 7. Powyżej 7 wielkość wskaźnika zaobserwowano w Estonii, natomiast dla Chin i Indii (prawdopodobnie $\mathrm{z}$ braku dokładnych danych) parametr ten wynosi 0,2 .

W większości krajów wymienionych w tab. 1 wskaźnik ryzyka $\mathbf{R}_{2}$ (średnia liczba ofiar śmiertelnych na 100000 mieszkańców) nie przekracza wartości 1. Ryzyko utraty życia $\mathbf{R}_{3}$ w Rosji i trzech krajach bałtyckich jest kilkunastokrotnie większe i oscyluje w granicach 10 . Wartości ryzyka opisane w tab. 1 dotyczące Polski mieszczą się w granicach średniej. 


\section{SKALA POSZKODOWANYCH W BUDYNKACH MIESZKALNYCH W POLSCE}

W „Przeglądzie Pożarniczym” (Janik 2013: 5), w artykule dotyczącym diagnozy pożarowej autor przedstawia ogólną liczbę pożarów, jakie występują w Polsce, liczbę poszkodowanych w pożarach oraz częstość wystąpienia utraty życia w pożarze na 1 milion mieszkańców.

Dane w tab. 2 ilustrują ogólną liczbę pożarów, jakie występują w Polsce oraz ich skutki osobowe.

Tabela 2

Pożary i poszkodowani w pożarach w Polsce w latach 2002-2012

\begin{tabular}{|c|c|c|c|c|c|c|}
\hline \multirow[b]{2}{*}{ Rok } & \multirow[b]{2}{*}{$\begin{array}{l}\text { Pożary } \\
\text { ogółem }\end{array}$} & \multirow[b]{2}{*}{$\begin{array}{l}\text { Poszko- } \\
\text { dowani } \\
\text { w pożarach } \\
\text { ogółem }\end{array}$} & \multirow[b]{2}{*}{$\begin{array}{c}\text { Ranni } \\
\text { w pożarach }\end{array}$} & \multicolumn{3}{|c|}{ Ofiary śmiertelne } \\
\hline & & & & ogółem & $\begin{array}{l}\text { z wyłączeniem } \\
\text { pożarów będących } \\
\text { następstwem } \\
\text { wypadków } \\
\text { drogowych }\end{array}$ & $\begin{array}{c}\text { średnio } \\
\text { na } 1 \mathrm{mln} \\
\text { miesz- } \\
\text { kańców }\end{array}$ \\
\hline 2002 & 151026 & 2814 & 2327 & 487 & 431 & 11,3 \\
\hline 2003 & 220855 & 3454 & 2932 & 522 & 476 & 12,5 \\
\hline 2004 & 146728 & 3392 & 2911 & 481 & 446 & 11,7 \\
\hline 2005 & 184316 & 3739 & 3143 & 596 & 543 & 14,2 \\
\hline 2006 & 165190 & 3625 & 3059 & 566 & 568 & 14,9 \\
\hline 2007 & 151069 & 3639 & 3044 & 595 & 553 & 14,5 \\
\hline 2008 & 161744 & 4293 & 3699 & 594 & 534 & 14,0 \\
\hline 2009 & 159122 & 4527 & 3943 & 584 & 540 & 14,2 \\
\hline 2010 & 135555 & 4776 & 4251 & 525 & 481 & 12,6 \\
\hline 2011 & 171830 & 4912 & 4325 & 587 & 540 & 14,1 \\
\hline 2012 & 183847 & 4751 & 4186 & 565 & 523 & 13,6 \\
\hline Średnio & 166480 & 3993 & 3438 & 555 & 512 & 13,0 \\
\hline
\end{tabular}

Źródło: Janik (2013: 8).

W tym miejscu należy zadać pytanie, czy tego rodzaju dane są istotne w procesie badania ryzyka utraty zdrowia i życia w budynkach mieszkalnych.

W celu uzyskania bardziej szczegółowych odpowiedzi należy postawić następujące pytania dotyczące pożarów w budynkach mieszkalnych ${ }^{3}$ :

${ }^{3}$ Budynki jednorodzinne, w tym bliźniaki, zabudowa szeregowa, budynki wielorodzinne, budynki mieszkalne w gospodarstwach rolnych oraz inne obiekty mieszkalne, w szczególności altanki, barakowozy, domki letniskowe. 
- jaka jest liczba pożarów i rannych w pożarach w budynkach mieszkalnych?

- jaka jest liczba pożarów i osób śmiertelnych w pożarach w budynkach mieszkalnych?

- jaka jest liczba miejscowych zagrożeń i rannych w miejscowych zagrożeniach w budynkach mieszkalnych?

- jaka jest liczba pożarów i osób śmiertelnych w miejscowych zagrożeniach w budynkach mieszkalnych?

Badaną grupą obiektów z bazy danych statystycznych Komendy Głównej PSP są budynki jednorodzinne, w tym bliźniaki, zabudowa szeregowa, budynki wielorodzinne, budynki mieszkalne w gospodarstwach rolnych oraz inne obiekty mieszkalne, w szczególności altanki, barakowozy, domki letniskowe.

W tab. 3 przedstawiono liczbę pożarów w obiektach mieszkalnych oraz liczbę rannych i ofiar śmiertelnych (do analizy częstości wystąpienia zdarzenia przyjęto liczbę mieszkańców w Polsce $38 \mathrm{mln}$ ).

Tabela 3

Pożary i osoby poszkodowane w pożarach w Polsce w latach 2000-2006 w budynkach mieszkalnych

\begin{tabular}{|c|c|c|c|c|}
\hline Rok & Pożary mieszkań & Ranni & Ofiary śmiertelne & $\begin{array}{c}\text { Liczba pożarów ogółem } \\
\text { na 100 tys. mieszkańców }\end{array}$ \\
\hline 2000 & 23003 & 1243 & 353 & 60,53 \\
\hline 2001 & 22930 & 1342 & 377 & 60,34 \\
\hline 2002 & 24303 & 1411 & 368 & 63,96 \\
\hline 2003 & 25311 & 768 & 389 & 66,61 \\
\hline 2004 & 24859 & 1942 & 384 & 65,42 \\
\hline 2005 & 26156 & 2085 & 462 & 68,83 \\
\hline 2006 & 26457 & 1205 & 482 & 69,62 \\
\hline
\end{tabular}

Źródło: opracowanie własne na podstawie bazy danych KG PSP.

Z analizy tab. 3 wynika, że w latach $2000-2006$ był stały wzrost liczby pożarów, a także wzrost liczby ofiar śmiertelnych. Natomiast liczba osób rannych w analizowanych latach nie wykazuje trendu.

$\mathrm{W}$ tab. 4 przedstawiono liczbę miejscowych zagrożeń ${ }^{4} \mathrm{~W}$ obiektach mieszkalnych oraz liczbę rannych i ofiar śmiertelnych.

\footnotetext{
${ }^{4}$ Miejscowe zagrożenie - zdarzenie wynikające z rozwoju cywilizacyjnego i naturalnych praw przyrody, niebędące pożarem ani klęską żywiołową, stanowiące zagrożenie dla życia, zdrowia,
} 
Miejscowe zagrożenia i poszkodowani w miejscowych zagrożeniach w Polsce w latach 2000-2006 w budynkach mieszkalnych

\begin{tabular}{|c|c|c|c|c|}
\hline Rok & $\begin{array}{c}\text { Miejscowe zagrożenia } \\
\text { w mieszkaniach }\end{array}$ & Ranni & $\begin{array}{c}\text { Ofiary } \\
\text { śmiertelne }\end{array}$ & $\begin{array}{c}\text { Liczba miejscowych zagrożeń } \\
\text { ogółem na 100 tys. mieszkańców }\end{array}$ \\
\hline 2000 & 64436 & 668 & 262 & 169,57 \\
\hline 2001 & 94636 & 820 & 380 & 249,04 \\
\hline 2002 & 116046 & 1112 & 392 & 305,38 \\
\hline 2003 & 100364 & 1452 & 514 & 264,12 \\
\hline 2004 & 112086 & 1696 & 532 & 294,96 \\
\hline 2005 & 115066 & 2112 & 568 & 302,81 \\
\hline 2006 & 164382 & 2352 & 648 & 432,58 \\
\hline
\end{tabular}

Źródło: opracowanie własne na podstawie bazy danych KG PSP.

Liczba miejscowych zagrożeń obejmujących działania w budynkach mieszkalnych na przestrzeni analizowanych lat wzrosła trzykrotnie, liczba osób śmiertelnych - dwukrotnie, a rannych - czterokrotnie. Ten znaczący wzrost może być spowodowany zacieśnianiem współpracy przy likwidowaniu zdarzeń przez takie podmioty, jak policja czy pogotowie ratunkowe (straż pożarna w ramach pomocy innym służbom wzywana jest do zdarzeń, przy których wcześniej nie brała udziału).

Z powyższych danych można wyliczyć częstość powstania szkody na osobie w budownictwie mieszkaniowym w czasie pożaru w Polsce. Jako liczbę obserwacji przyjęto straty osobowe (ranni i ofiary śmiertelne) w pożarach i miejscowych zagrożeniach w budynkach mieszkalnych. Natomiast jako próbę statystyczną przyjęto liczbę mieszkańców Polski. Wyniki obliczeń zawarte są w tab. 5.

Tabela 5

Częstość szkody osobowej w pożarach i miejscowych zagrożeniach w Polsce w latach 2000-2006 w budynkach mieszkalnych

\begin{tabular}{|c|c|c|c|c|}
\hline Rok & $\begin{array}{c}\text { Częstość }- \text { ranni } \\
\text { w pożarze }\end{array}$ & $\begin{array}{c}\text { Częstość }- \text { ofiary } \\
\text { śmiertelne } \\
\text { w pożarze }\end{array}$ & $\begin{array}{c}\text { Częstość }- \text { ranni } \\
\text { w miejscowych } \\
\text { zagrożeniach }\end{array}$ & $\begin{array}{c}\text { Częstość }- \text { ofiary } \\
\text { śmiertelne w miejscowych } \\
\text { zagrożeniach }\end{array}$ \\
\hline 1 & 2 & 3 & 4 & 5 \\
\hline 2000 & $3,27 * 10^{-5}$ & $0,93 * 10^{-5}$ & $1,76^{*} 10^{-5}$ & $0,69 * 10^{-5}$ \\
\hline
\end{tabular}

mienia lub środowiska, któremu zapobieżenie lub którego usunięcie skutków nie wymaga zastosowania nadzwyczajnych środków. 


\begin{tabular}{|c|c|c|c|c|}
\hline 1 & 2 & 3 & 4 & 5 \\
\hline 2001 & $3,53 * 10^{-5}$ & $0,99 * 10^{-5}$ & $2,16^{*} 10^{-5}$ & $1,00^{*} 10^{-5}$ \\
\hline 2002 & $3,71 * 10^{-5}$ & $0,97 * 10^{-5}$ & $2,93 * 10^{-5}$ & $1,03 * 10^{-5}$ \\
\hline 2003 & $2,02 * 10^{-5}$ & $1,02 * 10^{-5}$ & $3,82 * 10^{-5}$ & $1,35^{*} 10^{-5}$ \\
\hline 2004 & $5,11 * 10^{-5}$ & $1,01 * 10^{-5}$ & $4,46 * 10^{-5}$ & $1,40^{*} 10^{-5}$ \\
\hline 2005 & $5,49 * 10^{-5}$ & $1,22 * 10^{-5}$ & $5,56 * 10^{-5}$ & $1,49 * 10^{-5}$ \\
\hline 2006 & $3,17 * 10^{-5}$ & $1,27 * 10^{-5}$ & $6,19 * 10^{-5}$ & $1,71 * 10^{-5}$ \\
\hline
\end{tabular}

Źródło: opracowanie własne na podstawie bazy danych KG PSP.

Tabela 5 ukazuje zmiany w częstości szkód osobowych w pożarach i miejscowych zagrożeniach, które kształtują się na poziomie jedna lub dwie ofiary śmiertelne na sto tysięcy mieszkańców. Natomiast osoby ranne to zakres od dwóch do sześciu osób na sto tysięcy mieszkańców.

W czasie likwidowania zdarzenia niepożądanego, jakim jest pożar, występują również straty osobowe strażaków. W tab. 6 przedstawiono liczbę pożarów w obiektach mieszkalnych oraz liczbę rannych i ofiar śmiertelnych wśród strażaków PSP.

Tabela 6

Pożary i poszkodowani wśród strażaków w pożarach w Polsce w latach 2000-2006 w budynkach mieszkalnych

\begin{tabular}{|c|c|c|c|c|}
\hline Rok & Pożary & Ranni & $\begin{array}{c}\text { Ofiary } \\
\text { śmiertelne }\end{array}$ & $\begin{array}{c}\text { Liczba pożarów } \\
\text { na 100 tys. mieszkańców }\end{array}$ \\
\hline 2000 & 23003 & 152 & 1 & 60,53 \\
\hline 2001 & 22930 & 91 & 0 & 60,34 \\
\hline 2002 & 24303 & 88 & 0 & 63,96 \\
\hline 2003 & 25311 & 115 & 3 & 66,61 \\
\hline 2004 & 24859 & 114 & 2 & 65,42 \\
\hline 2005 & 26156 & 123 & 0 & 68,83 \\
\hline 2006 & 26457 & 108 & 1 & 69,62 \\
\hline
\end{tabular}

Źródło: opracowanie własne na podstawie bazy danych KG PSP.

Z tab. 5 wynika, że średnia liczba ofiar śmiertelnych wśród strażaków jest na poziomie jednej osoby. Natomiast występuje nieregularna zmienność liczby rannych strażaków w pożarach. 


\section{UWARUNKOWANIA, SKUTKI I PRZYCZYNY POŻARÓW MIESZKAŃ}

Mieszkania w budynkach wielorodzinnych są traktowane jako swoistego rodzaju strefa pożarowa ${ }^{5}$, za którą pożar nie powinien się przedostać. Praktyka jednak wskazuje na to, że pożary w zależności od tego, w jakim obiekcie powstają, charakteryzują się zmienną dynamiką w zakresie wzrostu temperatury i ilości produkowanych gazów pożarowych. Rozwój oraz szybkość rozprzestrzeniania się pożaru jest uzależniona od sposobu budowy oraz użytych materiałów budowlanych. Budynki, które powstały przed II wojną światową, były wykonane w technologii murowanej oraz drewnianej (stropy drewniane, klatka schodowa drewniana lub betonowa oraz palna więźba dachowa) i są niezwykle podatne na szybki rozwój pożaru. W budynkach mieszkalnych wykonanych w technologii tzw. wielkiej płyty i technologii tradycyjnej (elementy budowlane budynku wykonane z materiałów niepalnych) pożar w przeważającej większości przypadków kończy się w jednym mieszkaniu.

Jedną z przyczyn powstania pożaru jest wadliwa instalacja elektryczna wykonana na bazie przewodów aluminiowych (miejsca styku podatne są na utlenienia i utratę przewodności), co może powodować powstawanie zwarć i przepięć, w wyniku których dochodzi do pożaru.

Osoby przebywające w mieszkaniu są narażone na utratę zdrowia i życia $\mathrm{z}$ uwagi na różnego rodzaju zagrożenia, jakie występują w związku z funkcjonowaniem budynków mieszkalnych. Należy wymienić następujące rodzaje zagrożeń generujące możliwość powstania strat osobowych (osoby ranne i śmiertelne):

- katastrofę budowlaną;

- wybuch gazu;

- pożar i gazy pożarowe;

- zatrucie tlenkiem węgla;

- porażenie prądem elektrycznym;

- i inne.

${ }^{5}$ Strefę pożarową określa: $§ 226$ Rozporządzenia Ministra Infrastruktury z dnia 12 kwietnia 2002 r. w sprawie warunków technicznych, jakim powinny odpowiadać budynki i ich usytuowanie.

$\S 226$ Strefa pożarowa - pojęcie:

1. Strefę pożarową stanowi budynek albo jego część oddzielona od innych budynków lub innych części budynku elementami oddzielenia przeciwpożarowego, o których mowa w § 232 ust. 4, bądź też pasami wolnego terenu o szerokości nie mniejszej niż dopuszczalne odległości od innych budynków, określone w $\S 271$ ust. 1-7.

2. Częścią budynku, o której mowa w ust. 1, jest także jego kondygnacja, jeżeli klatki schodowe i szyby dźwigowe w tym budynku spełniają co najmniej wymagania określone w $\S 256$ ust. 2 dla klatek schodowych.

3. Powierzchnia strefy pożarowej jest obliczana jako powierzchnia wewnętrzna budynku lub jego części, przy czym wlicza się do niej także powierzchnię antresoli (Dz. U. 2002 nr 75, poz. 690). 
Bardzo groźnym, a jednocześnie trudnym do wykrycia zagrożeniem jest tlenek węgla. Jest on potocznie zwany czadem - gazem silnie trującym, bezbarwnym i bezwonnym, nieco lżejszym od powietrza. Tlenek węgla łatwo się miesza i rozprzestrzenia w powietrzu. Powstaje w wyniku niepełnego spalania wielu paliw, m.in.: drewna, oleju, gazu, benzyny, nafty, propanu, węgla, ropy, spowodowanego brakiem odpowiedniej ilości tlenu, niezbędnej do zupełnego spalania. Tlenek węgla jest szczególnie groźny w mieszkaniach, w których okna są szczelnie zamknięte lub uszczelnione na zimę.

Czad dostaje się do organizmu przez układ oddechowy, a następnie jest wchłaniany do krwioobiegu. W układzie oddechowym człowieka tlenek węgla wiąże się z hemoglobiną 210 razy szybciej niż tlen, blokując dopływ tlenu do organizmu. Stwarza to poważne zagrożenie dla zdrowia i życia człowieka. Uniemożliwia prawidłowe rozprowadzanie tlenu we krwi i powoduje uszkodzenia mózgu oraz innych narządów. Następstwem ostrego zatrucia może być nieodwracalne uszkodzenie ośrodkowego układu nerwowego, niewydolność wieńcowa i zawał albo nawet śmierć.

W celu uniknięcia zatrucia tlenkiem węgla należy unikać sytuacji, w których wystąpi brak dopływu świeżego (zewnętrznego) powietrza do urządzenia, w którym następuje spalanie. Podstawową przyczyną zatruć jest niepełne spalanie, do którego może dojść np. gdy zbyt szczelnie zamknięte są okna i brak jest właściwej wentylacji. Powoduje to powstawanie tlenku węgla i utrudnia jego odpływ.

Urządzenia gazowe powinny być utrzymywane w czystości i w dobrym stanie technicznym, a także okresowo kontrolowane zgodnie z zaleceniami producenta. Obowiązek utrzymania wymaganego stanu technicznego urządzeń gazowych i ich udostępnienia do kontroli spoczywa na użytkowniku lokalu. . W trosce o bezpieczeństwo własne i swojej rodziny do tego obowiązku powinien się poczuwać każdy użytkownik urządzeń gazowych.

\section{KIERUNKI DZIALAŃ PREWENCYJNYCH W ZAKRESIE OGRANICZENIA LICZBY POSZKODOWANYCH W POŻARACH W POLSCE}

Działania i rozwiązania, jakie są podejmowane w celu poprawy bezpieczeństwa funkcjonowania budynku, powinny być realizowane w takich obszarach, jak:

- działania organizacyjno-prawne - utrzymanie porządku i ładu, przeprowadzanie okresowych przeglądów instalacji technicznych, ograniczanie występowania materiałów palnych w miejscach do tego niewyznaczonych;

\footnotetext{
${ }^{6}$ Rozporządzenie Ministra Spraw Wewnętrznych i Administracji z dnia 16 sierpnia 1999 r. w sprawie warunków technicznych użytkowania budynków mieszkalnych (Dz. U. z dnia 9.09.1999 nr 74 poz. $836, \S 17$ ust. 1 i 2).
} 
- inwestycje budowlane ograniczające rozwój pożaru (tzw. zabezpieczenia bierne) - wykonywanie budynku z materiałów niepalnych, wyposażanie obiektu wykonane z trudno zapalnych materiałów, poszczególne mieszkania w budynku wydzielone pożarowo (drzwi przeciwpożarowe w klasie EI30 do mieszkania z klatki schodowej);

- inwestycje w systemy przeciwpożarowe - tzw. zabezpieczenia czynne, system sygnalizacji pożarowej (czujki autonomiczne lub systemy z centralami), system wentylacji pożarowej oraz systemy gaśnicze (stosowane wyjątkowo w budownictwie mieszkaniowym).

Domowe czujki dymu znajdują nabywców w wielu krajach na świecie. Wynika to ze świadomości, że w warunkach pożaru ryzyko utraty życia gwałtownie rośnie. Badania w Wielkiej Brytanii i USA potwierdziły, że zastosowanie urządzeń wczesnego ostrzegania o pożarze redukuje ryzyko śmierci o około $40 \%{ }^{7}$.

W Polsce przepisy prawa nie zobowiązują właściciela mieszkania do wyposażenia go w system sygnalizacji pożaru. Pomimo braku obowiązku instalowania tego typu urządzeń w domach w Polsce spotyka się coraz częściej indywidualne ich instalowanie w mieszkaniach.

Duży wpływ na obecną liczbę ofiar śmiertelnych i poszkodowanych wśród społeczeństwa ma niski poziom świadomości w zakresie bezpieczeństwa pożarowego. Mówiąc o świadomości, mamy na myśli obszar wiedzy pozwalającej na wykrycie ewentualnych zagrożeń mogących przyczynić się do powstania pożaru. Brak wiedzy dotyczącej podstawowych zaniedbań w zakresie bezpieczeństwa pożarowego, np. obluzowane gniazdko, przechowywanie kartonów lub innych materiałów palnych w sąsiedztwie źródeł ciepła, może być źródłem pożaru. Chociaż powstanie pożaru w znaczeniu globalnym w budownictwie mieszkaniowym nie jest kwestionowane przez społeczeństwo, to w odniesieniu do swojego mieszkania nie dopuszcza się myśli o możliwości powstania pożaru, argumentując to w różnoraki sposób.

\section{PODSUMOWANIE I WNIOSKI}

W artykule ukazano liczbę osób poszkodowanych w pożarach w budynkach mieszkalnych oraz propozycje jej zmniejszania. Reasumując:

${ }^{7} \mathrm{~W}$ ciągu 30 lat obecności domowych czujek dymu na świecie znalazły one uznanie jako doskonałe urządzenia detekcji w takich instytucjach, jak ANSI (American National Standards Institute), AS (Australian Standard), BS (British Standard), ULC (Underwriters Laboratories Canada) i ULI (Underwriters Laboratories Inc). Świadczy to o dużej wadze, jaką przykłada się w niektórych krajach do prostych urządzeń wczesnego ostrzegania o pożarze. W takich krajach, jak Nowa Zelandia, Wielka Brytania, Stany Zjednoczone, Kanada domowe czujki dymu uratowały życie wielu osobom, które nieświadomie znalazły się w niebezpieczeństwie. 
- liczba poszkodowanych w pożarach w Polsce na przestrzeni analizowanych lat nie zmniejsza się (a nawet miała tendencję wzrostową pomimo prowadzonych akcji edukacyjnych i apeli);

- pożary mieszkań, w których giną ludzie, powstają zarówno w krajach rozwiniętych, jak i rozwijających się. Poziom rozwoju gospodarczego i świadomości mieszkańców ma wpływ na częstość występowania pożarów w mieszkaniach oraz na wielkość szkód osobowych i materialnych;

- działaniem, które wpływa na zmniejszenie strat, jest instalowanie czujek dymu lub tlenku węgla. Zalecane zasady rozmieszczania czujek domowych opierają się przede wszystkim na umieszczeniu czujki w korytarzu na każdej z kondygnacji.

W artykule szerzej opisano zagrożenie związane z powstawaniem tlenku węgla oraz skutkami, jakie wywołuje on u ludzi przebywających w jego atmosferze.

Należy zadać sobie pytanie, w jaki sposób zachęcić lub ,przymusić” właścicieli i lokatorów budynków mieszkalnych do instalowania czujek dymu i tlenku węgla. Jaką rolę w tym działaniu powinny odegrać np. towarzystwa ubezpieczeniowe?

Pomimo wysiłku badawczego nie udało się ukazać całości podejmowanej tematyki. Należałoby przeprowadzić dalsze pogłębione badania w zakresie szkód osobowych i wartości strat pożarowych.

\section{BIBLIOGRAFIA}

Bruhlinsky N. N., Sokolov S. V., Wagner P., Hall jun. J. R. (2008), Światowa statystyka ochrony przeciwpożarowej i ratownictwa. Raport $n$ r 13. Ocena ryzyka powstania pożaru, thum. J. Kielin, Fundacja Edukacji i Technika Ratownictwa.

Dubisz S. (red.), (2003), Uniwersalny słownik języka polskiego, t. 5, PWN, Warszawa.

Flis J., Jakubczak R. (2006), Bezpieczeństwo narodowe Polski w XXI wieku, wyzwania i strategie, Bellona, Warszawa.

Janik P. (2013), Diagnoza pożarowa, „Przegląd Pożarniczy”, nr 11.

Kołodziński E. (2004), Zagrożenia bezpieczeństwa i organizacja przeciwdziałania ich skutkom, XII Konferencja naukowa. Automatyzacja dowodzenia, 2-4 czerwca 2004 r., Gdynia-Jurata.

PN-IEC 60300-3-9, Analiza ryzyka w systemach technicznych. Zarządzanie niezawodnościa, przewodnik zastosowań.

Rozporządzenie Ministra Infrastruktury z dnia 12 kwietnia 2002 r. w sprawie warunków technicznych, jakim powinny odpowiadać budynki i ich usytuowanie (Dz. U. 2002 nr 75, poz. 690).

Rozporządzenie Ministra Spraw Wewnętrznych i Administracji z dnia 16 sierpnia 1999 r. w sprawie warunków technicznych użytkowania budynków mieszkalnych (Dz. U. z dnia 9.09.1999 nr 74 , poz. $836, \S 17$ ust. 1 i 2 ).

Sobol E. (red.), (2002), Nowy stownik języka polskiego, PWN, Warszawa.

Stańczyk R. (1996), Współczesne postrzeganie bezpieczeństwa, PAN, Warszawa.

Wielka encyklopedia powszechna (1962), PWN, Warszawa. 
Jacek Mikołaj Konciak

\title{
PERSONAL INJURY CAUSED BY FIRES IN RESIDENTIAL BUILDINGS IN POLAND IN 2000-2006
}

\begin{abstract}
The article presents the problem of casualties in fires apartments in Poland in the years 2000-2006. Each year lose their lives in fires about 500 people. Most victims of fires falls on housing, of which $60-70 \%$ of these cases the victim is in contact with the fumes and toxic combustion products. The article presents the reasons for such high casualties, and proposes a solution which will significantly contribute to improving the safety of residents.
\end{abstract}

Keywords: fire hazard, fire risk, firesafety, smoke detector. 